\title{
Role of methyleprednisolone succinate in the management of acute spinal cord injury
}

\author{
NK Karn, BP Shrestha, GP Khanal, R Rijal, P Chaudhary, IP Mahato, N Das \\ B.P. Koirala Institute of Health Sciences, Dharan, Nepal
}

\begin{abstract}
Objective: To see the role of methyleprednisolone succinate in the management of acute spinal cord injury. Methods: A randomized control trial was done including the patients with acute spinal cord injury. They were divided into age and gender matched two groups. Patients with presence of active infection, associated open fracture, those on long term steroid and those who did not give consent to participate in the trial were excluded. One group received methyleprednisolone succinate within 8 hours of injury and another group did not receive the drug. Both the groups were managed nonoperatively. The neurological status of the patients was assessed at presentation, once spinal shock was over, at $6^{\text {th }}$ week and $6^{\text {th }}$ month and after one year according to ASIA scoring. Frankel grading was also assessed in every follow up. Conclusion: Methylprednisolone succinct prevents secondary cord injury to a great extent and hence its administration within 8 hours of injury results in a better functional (motor and sensory) outcome.
\end{abstract}

Keywords: acute spinal cord injury, methyleprednisolone succinate

\section{Introduction \\ Traumatic spinal cord injury is a formidable challenge for the injured, for the treating team, for family and friends, and for the society as a whole. The worldwide incidence is $9.2-50$ patients per million population per year. ${ }^{1}$ The spinal cord injury is one of the commonest causes of disability in developing countries like Nepal. Therefore, every effort should be made to reduce the burden of the disease. One The spinal cord can get injured by direct force damaging the cord due to primary mechanical injury. In addition to this, the spinal cord undergoes secondary injury by a variety of pathological processes, including ischemia, calcium influx, lipid peroxidation, excitotoxic mechanisms and free radical activation. We do not have control on primary mechanical injury but there are various methods to reduce secondary injury.}

Address for correspondence

Navin Kumar Karn, Associate Professor

Department of Orthopaedics

B. P. Koirala Institute of Health Sciences, Dharan, Nepal.

E-mail: navinkarn@yahoo.com
Methylprednisolone succinate steroid has been shown to be effective in enhancing neurological recovery in acute spinal cord injury ${ }^{2}$. There are a number of studies which have shown significant improvement in neurological recovery with the use of high dose of methylprednisolone succinate. There are few studies which say that the methyprednisolone should not be considered as the standard treatment. Therefore, the present prospective randomized control trial was conducted to see the role of methyleprednisolone succinate in the management of acute spinal cord injury.

\section{Methods}

The patients with acute spinal cord injury due to cervical spine injury presenting to B P Koirala Institute of Health Sciences (BPKIHS), Dharan, Nepal and its teaching district hospitals within 8 hours of the injury and giving written consent were included in the study. The patients with presence of active infection, associated open fracture, patients on long term steroid and those who did not give consent were 
excluded. After obtaining a detailed history and examination, investigations like plain radiographs were done in all the cases.

The local doctors of teaching district hospitals of BPKIHS were trained by one of the investigators regarding randomization number, dose, mode of administration and duration of administration of methylprednisolone succinate and explained the importance of administration of this drug as early as possible following spinal cord injury. The patients were randomly allocated into the prednisolone group and the conventional group. After exclusion, there were 24 patients in prednisolone group and 26 patients in conventional group. Prednisolone group received methylprednisolone succinate in a bolus intravenous dose of $30 \mathrm{mg} / \mathrm{kg}$ body weight over a 15 minutes period followed by a maintenance dose of $5.4 \mathrm{mg} / \mathrm{kg} / \mathrm{hr}$ infusion afterwards for next 23 hours to the patients who present within 3 hours of injury to the hospital and continued for next 47 hours if patient presented more than 3 hours and within 8 hours of injury. The conventional group received the usual conventional treatment that included treatment with crutch field traction for 6 weeks followed by four post brace for 6 weeks. After 3 months depending on clinico- radiological assessment, further continuation of brace was prescribed. The neurological status of the patients was assessed at presentation, once spinal shock was over, at 6 week and 6 months and one year according to the American Spinal Injury Association (ASIA) scoring system and compared between both the groups. Frankel grading was assessed at every follow up. This study was approved by the institutional ethics committee.

The data were entered using Microsoft EXCEL verson 8 (Microsoft Corporation, Redmond, Washington). The success of the randomisation was tested by comparing descriptive variables such as age, gender, laboratory parameters and mechanism of injury. Any discrepancies were measured as the difference between the means in both groups. The significance of these differences was measured using parametric analysis of variance, student t-test or the non-parametric Menn-Whitney test derived from the Epi Info computer program.

\section{Results}

Both groups were comparable in terms of age, gender, laboratory parameters mechanism of injury etc $(p>0.05)$ (Table 1) The cervical spine injury was seen mostly in male because earning member in the family is male and they have to go out. The majority of the patients could be brought to the hospital only after 3 hours and the reason was transportation problems. Most of the patients had incomplete spinal cord injury.

\section{Table No. 1: Testing Randomization}

The two groups were similar on the following patient/ injury parameters as shown in table 1

\begin{tabular}{|c|c|c|c|c|c|c|}
\hline \multirow[t]{2}{*}{ S.N. } & \multirow{2}{*}{\multicolumn{2}{|c|}{ Variable }} & \multicolumn{2}{|c|}{$\begin{array}{c}\text { Mean } \pm \text { SD/Number } \\
\text { of patients }\end{array}$} & \multirow{2}{*}{$\begin{array}{l}\text { Difference/ } \\
\text { Odds ratio } \\
(95 \% \text { C.I. })\end{array}$} & \multirow[t]{2}{*}{$\mathrm{P}$ value } \\
\hline & & & $\begin{array}{l}\text { Prednisolone } \\
\text { group }\end{array}$ & $\begin{array}{l}\text { Conventional } \\
\text { group }\end{array}$ & & \\
\hline 1 & Age & & $31.25 \pm 16.98$ & $32.23 \pm 18.27$ & $0.98 \pm 1.29$ & 0.84 \\
\hline 2 & Gender & $\begin{array}{l}\text { Males } \\
\text { Females }\end{array}$ & $\begin{array}{c}18 \\
6\end{array}$ & $\begin{array}{c}21 \\
5\end{array}$ & $0.71(0.15,3.28)$ & 0.88 \\
\hline 3 & Occupation & $\begin{array}{l}\text { Dependants } \\
\text { Non dependants }\end{array}$ & $\begin{array}{l}12 \\
12\end{array}$ & $\begin{array}{l}14 \\
12\end{array}$ & $0.86(0.24,3.01)$ & 0.99 \\
\hline 4 & Lab parameters & $\begin{array}{l}\text { Hemoglobin }(\mathrm{gm} \%) \\
\text { Total Protein }(\mathrm{gm} \%) \\
\text { Random Blood Sugar }(\mathrm{mg} \%)\end{array}$ & $\begin{array}{c}10.14 \pm 2.24 \\
6.41 \pm .87 \\
101.12 \pm 38.85 \\
\end{array}$ & $\begin{array}{c}10.042 \pm 2.22 \\
6.13 \pm .87 \\
95.57 \pm 24.50 \\
\end{array}$ & $\begin{array}{c}0.10 \pm 0.02 \\
0.28 \pm 0.0048 \\
5.54 \pm 14.35 \\
\end{array}$ & $\begin{array}{l}0.8709 \\
0.2600 \\
0.5455\end{array}$ \\
\hline 5 & $\begin{array}{l}\text { Mechanism of } \\
\text { injury }\end{array}$ & $\begin{array}{l}\text { Fall } \\
\text { RTAFarm animal related }\end{array}$ & $\begin{array}{l}14 \\
82 \\
\end{array}$ & $\begin{array}{l}16 \\
82 \\
\end{array}$ & 2.33 & 0.233 \\
\hline 6 & $\begin{array}{l}\text { Injury Hospital } \\
\text { duration }\end{array}$ & $\begin{array}{l}<3 \text { hours } \\
\text { 3-8hours }\end{array}$ & $\begin{array}{c}4 \\
20 \\
\end{array}$ & $\begin{array}{c}2 \\
24 \\
\end{array}$ & 1.13 & 0.91 \\
\hline 7 & Bony injuries & $\begin{array}{l}\text { Fracture of vertebra } \\
\text { Fracture dislocation }\end{array}$ & $\begin{array}{c}6 \\
18 \\
\end{array}$ & $\begin{array}{c}6 \\
20 \\
20\end{array}$ & $\begin{array}{c}1.11 \\
(0.25,4.88) \\
\end{array}$ & 0.86 \\
\hline 8 & $\begin{array}{l}\text { Neurological } \\
\text { involvement }\end{array}$ & $\begin{array}{l}\text { Complete } \\
\text { Incomplete }\end{array}$ & $\begin{array}{c}9 \\
15\end{array}$ & $\begin{array}{c}8 \\
18\end{array}$ & $\begin{array}{c}1.27 \\
(0.34,4.88)\end{array}$ & 0.91 \\
\hline
\end{tabular}


At final follow up at one year we observed that change in ASIA scoring for motor as well as sensory was significantly more in prednisolone group and final Frankel grading was also better in prednisolone group (Table 2). Neck pain was present in majority of cases in both the groups. On using regression analysis it was observed that younger patients, female sex, incomplete spinal cord injury and methyle prednisolone succinate therapy had the strongest association with better neurological recovery.

Table No. 2: Comparing outcomes

\begin{tabular}{|l|l|c|c|c|c|}
\hline SN & Variables & \multicolumn{2}{|c|}{ Mean \pm SD/Number of patients } & pValue & $\begin{array}{c}\text { Kruskall- } \\
\text { Wallis }\end{array}$ \\
\cline { 3 - 5 } & & $\begin{array}{c}\text { Prednisolone } \\
\text { Group }\end{array}$ & $\begin{array}{c}\text { Conventional } \\
\text { group }\end{array}$ & & \\
\hline 1 & Change in ASIA Scoring (motor) at 1 year & 22 & 12 & 0.0042 & 0.0028 \\
2 & Change in ASIA Scoring (sensory)at 1 year & 24 & 12 & 0.0112 & 0.0097 \\
3 & Change in Frankel grading at 1year & 3 & 1 & 0.040 & 0.030 \\
4. & Neck pain at 1 year & 14 & 16 & 0.234 & 0.240 \\
\hline
\end{tabular}

\section{Discussion}

It is estimated that injury $37-55 \%$ of patients with cervical spine injury also have spinal cord injury. The majority of such occurs between $\mathrm{C} 4$ and C6 level, as the cervical canal is narrowest at this level. In the West and industrialized world, road traffic accidents account for $36 \%$ to $57 \%$ of cervical spine injury. However, in our region, mostly the injuries are due to fall from trees, horses, bicycles etc., besides road traffic accidents. The possible reason for a fall from a tree is that the people climb up a tree to get grass for their cattle in hilly areas.

Bracken et $\mathrm{al}^{2}$ performed a randomized control trial in 10 hospitals with 487 patients and showed methylprednisolone succinate to be effective in enhancing neurological recovery in acute spinal cord injury. They encountered infections and pulmonary embolism as complications which was not observed in our study.

High dose of methylprednisolone preserves the cord ultrastructure through a reduction of injury-induced, free radical catalyzed lipid peroxidation, when given within eight hours after injury. Patients treated with methylprednisolone show significant improvement when followed at six weeks and six months after the injury as compared to the patients who did not receive the drug. ${ }^{3}$ The dose of methylprednisolone far exceeds the dose necessary to activate corticosteroid receptors. This suggests that methylprednisolone may act through mechanisms unrelated to corticosteroid receptors. High dosage of methylprednisolone markedly enhances the flow of blood in injured spinal cords, preventing the typical decline in white-matter blood flow, extracellular calcium levels and evoked potentials that occur after spinal cord injury. ${ }^{3-5}$

The doses required for a treatment effect are similar to those shown to be the most effective in inhibiting lipid peroxidation and breakdown of neurofilament in injured spinal cord. ${ }^{6}$ These events in the breakdown of membrane begin and peak within eight hours of injury. A secondary effect of the inhibition of lipid peroxidation is that vasoreactive by-products of arachidonic acid metabolism are reduced, which improves the flow of blood at the injury site. Bracken et al concluded High-dose MPSS given within 8 hours of acute spinal cord injury was a safe and modestly effective therapy that may result in important clinical recovery for some patients. ${ }^{3}$

The Canadian Neurosurgical Society, the Canadian Spine Society and Canadian Association of Emergency Physicians have adopted the committee's recommendation that a high-dose, 24 hour infusion of methylprednisolone started within 8 hours after an acute closed spinal cord injury is not a standard treatment nor a guideline for treatment. ${ }^{7}$

There are three well-designed, large, randomized clinical trials (the National Acute Spinal Cord Injury Studies [NASCIS I, II and III]) which examined the effect of steroid administration in patients with acute spinal cord injury. $2,3,8-11$

NASCIS I examined the change in motor function in specific muscles and changes in light touch and pinprick sensation from baseline., ${ }^{3,8}$ The study detected no benefit from methylprednisolone, but the dose was considered to be below the therapeutic 
threshold determined from animal experiments. Therefore, NASCIS II used a much higher dose, and patients were randomly assigned to receive a 24-hourinfusion of methylprednisolone, naloxone or placebo within 12 hours after acute spinal cord injury. ${ }^{2,9}$. Again, there was nobenefit overall in the methylprednisolone group. However, post hoc analyses detected a small gain in the total motor and sensory score in a subgroup of patients who had received the drug within 8 hours after their injury. As a result, this 24-hour, high-dose methylprednisolone infusion, if started within 8 hours after injury, quickly became an implied standard of care despite considerable criticism of the validity of such a post hoc analysis. NASCIS III compared a 48-hour infusion of methylprednisolone with a 24 hour infusion started within 8 hours after injury and found no benefit fromextending the infusion beyond 24 hours. Again, only post hoc analysis showed a benefit from extending the infusion to 48 hours when treatment was started between 3 and 8 hours after injury. No other study has verified the primary outcome of 48 hours versus 24 hours or the post hoc conclusion of benefit from starting treatment between 3 and 8 hours after injury. A meta-analysis of all of the trials concluded, on the basis of the controversial subgroup post hoc analyses in NASCIS II and III and the data from the Japanese study, that a 24-hour high-dose methylprednisolone infusion within 8 hours after injury is efficacious

\section{Conclusion}

That the patients who recieved methyleprednisolone succinate showed better improvement in neurological status. Methylprednisolone succinate prevents secondary cord injury to a great extent and hence its administration within 8 hours of injury results in a better functional (motor and sensory) outcome. In Nepal, delay in reporting to a tertiary centre necessitates a strategy to train first contact physicians to administer the drug if the patient reports to them within the stipulated period.

\section{Acknowledgment}

The authors thank medical officers, paramedics at BPKIHS teaching district hospitals of BPKIHS for their help in completion of the study.

\section{References}

1. Rasool Tahir et al. Role of methylprednisolone in acute cervical cord injuries. Indian J Surg 2004; 66: 156-159

2. Bracken MB, Shepard MJ, Collins WF, Holford TR, Young W, Baskin DS et al. A randomized controlled trial of Methylprednisolone or naloxone in the treatment of acute spinal cord injury. New Eng J Med 1990;322:1405-11.

3. Bracken MB, Shepard MJ, Hellenbrand KG, Collins WF, Leo LS, Freeman DF et al. Methylprednisolone and neurological function one year after spinal cord injury. J Neurosurg 1985;63:704-13.

4. Hall ED, Wolf DL, Braughler JM. Effects of a single large dose of methylprednisolone sodium succinate on experimental post traumatic spinal cord ischemia. J Neurosurg 1984;61:124-30.

5. Braughler JM, Hall ED. Correlation of Methylprednisolone levels in cat spinal cord with its effects on $(\mathrm{Na}++\mathrm{K}+)$-ATPase, lipid peroxidation and alpha motor neuron function. $\mathrm{J}$ Neurosurg 1982;56:838-44.

6. Braughler JM, Hall ED. Effects of multidose methylprednisolone sodium succinate administration on injured cat spinal cord neurofilament degradation and energy metabolism. J Neurosurg 1984;61:290-5.

7. Hugenholtz $\mathrm{H}$, Methylprednisolone for acute spinal cord injury: not a standard of care. CMAJ 1986;134(7):721-9.

8. Bracken MB, Collins WF, Freeman DF, Shepard MJ, Wagner FW, Silten RM et al. Efficacy of methylprednisolone in acute spinal cord injury. JAMA 1984; 251(1):45-52.

9. Bracken MB, Shepard MJ, Collins WF Jr, Holford TR, Baskin DS, Eisenberg HM et al. Methylprednisolone or naloxone treatment after acute spinal cord injury: 1-year follow-up data. Results of the second National Acute Spinal Cord Injury Study. J Neurosurg 1992;76(1):23-31.

10. Bracken MB, Shepard MJ, Holford TR, LeoSummers L, Aldrich EF, Fazl M et al. Administration of methylprednisolone for 24 or 48 hours or tirilazad mesylate for 48 hours in the treatment of acute spinal cord injury. Results of the Third National Acute Spinal Cord Injury Randomized Controlled Trial. National Acute 
Spinal Cord Injury Study. JAMA 1997;277(20):1597-604.

11. Bracken MB, Shepard MJ, Holford TR, LeoSummers L, Aldrich EF, Fazl M et al. Methylprednisolone or tirilazad mesylate administration after acute spinal cord injury: 1year follow up. Results of the third National
Acute Spinal Cord Injury randomized controlled trial. J Neurosurg 1998;89(5):699-706.

12. Bracken MB. Pharmacological intervention for acute spinal cord injury [Cochrane review]. In: The Cochrane Library; Issue 1, 2001. Oxford: Update Software. 